\title{
Disaster management of Malaka district government in flood disaster management
}

\author{
Yulius N. Bria ${ }^{1}$, Nursalam Nursalam ${ }^{2}$, Laurensius P. Sayrani ${ }^{3}$ \\ Nusa Cendana University 1,2,3 \\ yuliusbria12@gmail.com ${ }^{1}$, nursalamjeppu@yahoo.com ${ }^{2}$, laurensayrani@yahoo.co.id ${ }^{3}$
}

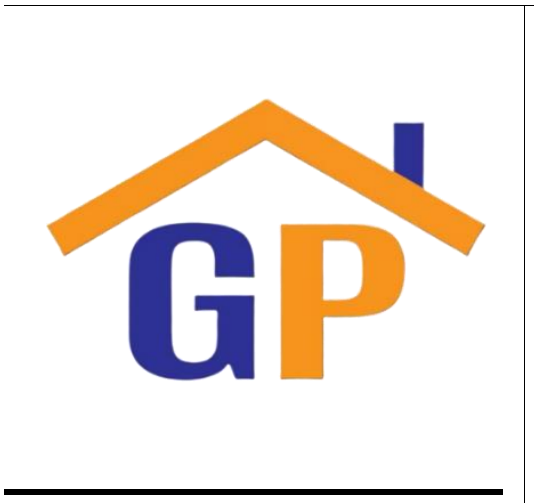

Article History

Received on 14 December 2020

Revised on 31 January 2021

Accepted on 4 February 2021

\begin{abstract}
Purpose: This study aimed to analyze the disaster management of the Malaka Regency Government in flood disaster management.

Research methodology: The research method used in this study is a qualitative research method. The informants in this study were elements of the government as well as elements of society consisting of the Flood Victims Community. The analysis technique in this study uses data analysis developed by Miles and Huberman (2014: 10) as follows; (a) data reduction (b) data display and (c) concluding.
\end{abstract}

Finding: The result of this research is that the Malaka Regency Government's disaster management in flood disaster management has implemented the best management even though it is still not optimal.

Limitation: This study's limitation is that this study only discusses the disaster management of the Malaka district government in overcoming the floods that occurred there.

Contribution: This research becomes scientific information for public administration and disaster management.

Keywords: Management, Disaster, Government

How to cite: Bria, Y. N., Nursalam, N., \& Sayrani, L. P. (2020). Disaster management of Malaka district government in flood disaster management. Annals of Management and Organization Research, 1(3), 171-185.

\section{Introduction}

Indonesia is one of the countries in the world that most frequently experiences various types of natural disasters. One of the most frequent natural disasters is flooding. Data from the National Disaster Management Agency (BNPB) published on Kompas.com (2020) shows that since 2015-2019, flood disasters have always occurred with great frequency. In 2015, there were 523 floods from a total of 1,691 natural disasters. The number of floods also increased rapidly in 2016 with 823 floods and in 2017 with 978 floods. In 2018, floods experienced a decline, with 679 floods from a total of 2,572 natural disasters in Indonesia. The flood frequency again decreased in 2019 with 343 floods. Based on these data, it can be said that floods are the most frequent disaster in Indonesian territory.

The magnitude of the frequency of flooding is inseparable from a large number of rivers in Indonesia. Indonesia has 5,590 main rivers and 600 rivers of which have the potential to cause flooding. The flood-prone areas covered by the main rivers reach 1.4 million hectares. Based on various studies that have been carried out, floods that hit three things, namely 1) human activities that cause spatial changes and have an impact on natural changes, 2) natural events such as very high rainfall, rising seawater, storms, etc. and 3) environmental damage such as loss of land cover crops in the catchment area, silting rivers due to sedimentation, narrowing of river channels and so on (Kustiyanto 2004).

Floods inundate the rice fields so that they cannot be harvested and destroy housing and settlements and destroy community socio-economic service facilities and public infrastructure and even take lives. The loss will be even more significant if economic and government activities are disrupted, even if it is stopped. In fact, community participation in the context of flood management is 
real. Especially in emergency response activities, floods create additional financial burdens for the state, especially to rehabilitate and restore damaged public facilities. This recovery also takes a long time to make it back to normal.

Disaster management is an inseparable part of national development, namely a series of disaster management activities before, during and after a disaster. Often the government only responds to disasters in part. Even disasters are only responded to with an emergency response approach (Badan Informasi Publik Departemen Komunikasi dan Informatika, 2007: 12). In fact, the government is responsible for implementing disaster management that focuses on post-disaster reconstruction and rehabilitation. This is an order from Law Number 24 of 2007 concerning Disaster Management. Articles 35 and 36 of Law Number 24 of 2007 concerning Disaster Management clearly mandate that each region in its disaster management efforts have a disaster management plan. Therefore, each region must have its natural disaster management, including flood-prone areas such as Malacca District.

In handling the problem of natural disasters, namely flooding in Malacca Regency, it is not new because it has the Benanain River, which is in the western part of Timor Island, Indonesia. This river is the longest and largest river in the West Timor region, with a length of about $132 \mathrm{Km}$. The Benanain River characteristics that have very extreme discharge fluctuations indicate that the Benanain River Basin is experiencing critical damage. This makes this river often experience major floods every year. The Benanain River overflow occurred in West Malacca District, Central Malacca Regency and Weliman Regency, Malacca Regency, NTT. These routine natural disasters have occurred for decades.

The Malacca government itself has made various efforts to prevent and overcome floods, such as the construction of flood-retaining embankments. However, these efforts were not enough to stop the flood disaster. The Benanain flood with a height of two meters occurred in 2017, destroying 36 villages in three sub-districts in Malacca Regency. Besides, the flood also hit 1,844 hectares of land and damaged the residents' rice and corn crops. The biggest victim of the Benanain River flood in Malacca Regency occurred in 2000, which killed 650 people. Meanwhile, in the last few years, it has not claimed any casualties but continues to unsettle the community and force residents to evacuate whenever a flood occurs.

The Malacca Regency Government's responsibility in tackling the floods of the Benanain River can also be seen from the annual budget allocation to deal with the floods from 2016-2019. Budget allocation can be seen in the table below:

Table 1.

Budget Allocations for Disaster Management in Malaka District

\begin{tabular}{|l|l|}
\hline Year & $\begin{array}{l}\text { Budget } \\
\text { Allocation }\end{array}$ \\
\hline 2016 & Rp.1.000.000.000 \\
\hline 2017 & Rp.3.000.000.000 \\
\hline 2018 & Rp.8.000.000.000 \\
\hline 2019 & Rp.8.000.000.000 \\
\hline
\end{tabular}

Source: BPBD of Malaka Regency, 2020

Based on the table above, it can be seen that the budget allocation for disaster management in Malacca Regency tends to increase every year. This is because floods continue to occur every year. That way, even though floods still occur, with countermeasures, flooding can be minimized.

In this study, three aspects are emphasized, namely pre-disaster, during a disaster and postdisaster or recovery management. This is motivated by the current situation, namely the flood disaster in the Benanain river that has been completed by the Malacca Regency government from pre-disaster to disaster, so that the flood disasters that often occur every year can be minimized by the Malacca Regency government. However, in the achievements of the Malacca Regency Government, of course several processes have been passed, for that researchers want to dig deeper into how the processes and stages that the Malacca Regency government has gone through in achieving these successes, are related to the post-disaster aspects which must also be an important concern by The Malacca Regency Government is still in the process of reconstruction, rehabilitation, repair/recovery of the impact of the 
Benanain river flood disaster. This can be seen in terms of housing for disaster victims, infrastructure that supports community activities, surrounding social conditions and is also related to community economic income. The Malacca Regency Government's important attention should be from predisaster to post-disaster in accordance with the mandate of Law Number 24 of 2007 concerning Disaster Management. Based on the explanation above, the writer is encouraged to conduct more indepth research on Disaster Management of the Malacca Regency Government in Flood Disaster Management.

\section{Literature review}

\subsection{Public management}

According to Terry (2003: 77), Public Management is a way of achieving predetermined goals through an activity. The main functions of public management as stated by Terry consist of: planning, organizing, actuating, and controlling (P.O.A.C). Each function is related to each other and forms a system where each element cannot be separated from one another. This means, in practice or process, the performance of public management of each work unit, office, or organization is a single system. Each function in management is difficult to separate from one another.

Management functions are basic elements that will always exist and are embedded in the management process, which will be used as a reference by managers in carrying out activities to achieve goals. Fayol first introduced the management function at that time, he mentioned five management functions, namely designing, organizing, ordering, and controlling (Fayol, 2010: 179). But now, these five functions have been summarized into three, namely:

1. Planning (planning) is thinking about what to do with the resources they have. Planning is done to determine the overall goals of the company and how best to meet those goals. Managers evaluate various alternative plans before taking action and then see if the selected plans are suitable and can be used to meet company goals. Planning is an essential process of all management functions because other functions cannot run without planning.

2. Organizing (organizing) is done to divide a considerable activity into smaller activities. Organizing makes it easier for managers to supervise and determine the people needed to carry out the tasks that have been divided. Organizing can be done by determining what tasks must be done, who should do them, how the tasks are grouped, who is responsible for the task, at which level decisions must be made.

3. Directing is an action to ensure that everyone in the group strives to achieve goals following managerial and business planning.

In addition, according to Dwiyanto (2010: 47), Public Management is an ability related to efforts to achieve certain goals by using people and various resources available in the organization in the most efficient way possible.

From the conceptual opinion on Public Management above, it can be concluded that Public Management is a combination of management functions such as planning, organizing, and controlling on the one hand, with human resources (HR), financial, physical, information and politics in a systemic unit associated with efforts to achieve certain goals by using people and various resources available in the organization in the most efficient manner possible.

\subsection{Disaster management}

Disaster management is a dynamic, continuous and integrated process to improve the quality of steps related to disaster observation and analysis as well as prevention, mitigation, preparedness, early warning, emergency response, rehabilitation and reconstruction of disasters (Law 24/2007).

Disaster management, according to Nurjanah (2011: 66) is a dynamic process regarding the functioning of disaster management functions such as planning, organizing, actuating, and controlling. The way it works includes prevention, mitigation, and emergency response preparedness and recovery. According to University of British Columbia (in bpbd.bogorkab.go.id, 2019), Disaster management establishes common goals and common values to encourage the parties involved (participants) to plan and face both potential and actual disasters. The objectives of disaster management in general are as follows: (1) To prevent and limit the number of human victims and damage to property and the environment; (2) Eliminating adversity and difficulties in the life and livelihood of the victim; (3) 
Returning disaster victims from the holding/refugee area to their original area if possible or relocating to a new area that is habitable and safe; (4) Restoring the functions of main public facilities, such as communication/transportation, drinking water, electricity and telephones, including restoring the economic and social life of the affected areas; (5) Reducing further damage and losses; (6) Laying down the necessary basics for the implementation of rehabilitation and reconstruction activities in the context of development.

In general, disaster management can be grouped into 3 stages with several activities that can be carried out starting from pre-disaster, during emergency response, and post-disaster.

1. Pre-Disaster Stage (covering prevention, mitigation, preparedness and early warning activities).

a. Prevention

Efforts are made to prevent disasters from occurring (if possible by eliminating the hazards). For example: Prohibiting burning of forests in cultivation, prohibiting rock mining in steep areas, and Prohibiting littering.

b. Disaster Mitigation (Mitigation)

Mitigation is a series of efforts to reduce disaster risk, either through physical development as well as awareness and increased capacity to face disaster threats. Mitigation activities can be carried out through a) spatial planning implementation; b) regulation of development, infrastructure development, building layout; and c) providing education, counseling and training both conventional and modern (Law Number 24 of 2007 Article 47 paragraph 2 concerning Disaster Management).

c. Preparedness

A series of activities carried out to anticipate disasters through organizing and through appropriate and efficient steps. Several forms of preparedness activities that can be carried out include: a) preparation and testing of disaster emergency management plans; b) organizing, installing and testing early warning systems; c) supply and preparation of supplies for the fulfillment of basic needs; d) organizing, outreach, training and rehearsal on emergency response mechanisms; e) preparation of evacuation sites; f) preparation of accurate data, information, and updating of procedures for disaster emergency response; and g) supply and preparation of materials, goods and equipment for the fulfillment of the restoration of infrastructure and facilities.

d. Early Warning

A series of activities to provide an immediate warning to the community about the possibility of a disaster in a place by the competent agency (Law 24/2007) or Efforts to provide warning signs that a disaster is likely to occur soon Giving early warning must: accessible, immediate, coherent, and official.

2. The stage when a disaster occurs including emergency response activities to alleviate temporary suffering, such as emergency relief and evacuation activities

a. Emergency Response

Emergency response is a series of activities that are carried out immediately at the time of a disaster to deal with the negative impacts, including rescue and evacuation of victims, property, the fulfillment of basic needs, protection, management of refugees, rescue, and restoration of infrastructure and facilities. Some of the activities carried out during the emergency response phase include: a) accurate and precise assessment of location, damage and resources; b) determining the status of a disaster emergency; c) rescue and evacuation of people affected by disasters; d) fulfillment of basic needs; e) protection of vulnerable groups; and f) immediate restoration of vital infrastructure and facilities (Law Number 24 Year 2007 Article 48 concerning Disaster Management).

b. Emergency Assistance (relief)

Emergency Assistance is an effort to provide assistance related to meeting basic needs in the form of: Food, clothing, temporary shelter, health, sanitation and clean water. 
3. The post-disaster stage according to (Wirawan, 2002: 34) which includes recovery, rehabilitation and reconstruction activities.

a. Recovery

Recovery is a series of activities to restore the community's condition and the environment by re-functioning institutions, infrastructure, and facilities by carrying out rehabilitation efforts. Several activities related to recovery are a) improving the environment in the disaster area; b) repair of public infrastructure and facilities; c) assisting with community housing repairs; d) social-psychological recovery; e) health services; f) reconciliation and conflict resolution; g) socio-economic and cultural recovery, and $\mathrm{j}$ ) restoration of public service functions.

b. Rehabilitation

Rehabilitation is the repair and recovery of all aspects of public or community services to an adequate level in post-disaster areas with the main objective of normalizing or running fairly all aspects of government and community life in postdisaster areas. Rehabilitation is carried out through the following activities: improvement of the disaster area environment, repair of public infrastructure and facilities, provision of assistance for community housing repairs, socio-psychological recovery, health services, reconciliation and conflict resolution, socio-economic and cultural recovery, restoration of security and order, restoration of government functions, and recovery of the public service function.

c. Reconstruction

Reconstruction is the formulation of policies and efforts as well as concrete, wellplanned, consistent and sustainable steps to permanently rebuild all infrastructure, facilities and institutional systems, both at government and community levels, with the main objective of growing and developing economic, social and cultural activities, upholding law and order, and the emergence of civil society's role and participation in all aspects of social life in post-disaster areas. The scope of the reconstruction program consisted of a physical reconstruction program and a nonphysical reconstruction program.

In researching and examining in depth the writings of the management of the Malaka Regency government, in this case the Regional Disaster Management Agency of Malaka Regency in the management of the Benanain River Flood disaster, the researchers used a disaster management model based on Law Number 24 of 2007 concerning Disaster Management which the researcher saw from 3 main things, namely: pre-disaster, during a disaster and after a disaster. The researcher chose a disaster management model because in general the disaster management of the Malaka Regency government in flood disaster management can be explained and elaborated based on the stages of disaster management described in Law Number 24 of 2007 concerning Disaster Management. So those from the research that the researchers have done, the findings of the disaster management of the Malaka Regency government, in this case, the Regional Disaster Management Agency of Malaka Regency, have constructed the following:

1. Insufficient budget/funds for disaster management from pre-disaster to post-disaster stages.

2. The embankment built by the Malaka district government in an effort to mitigate it is not optimal, because it can be seen that flooding is still frequent.

3. Basic disaster response training for civil society has not been carried out.

4. The availability of disaster response tools is not yet optimal, such as flood detection tools that are not yet available.

5. The thinking of the community is still primitive where when the flood occurs there are people who have to stay at home because they don't have the heart to leave their belongings

6. Damage to facilities and infrastructure due to flooding.

7. Due to their agricultural products, big losses from the surrounding community were swallowed up by the Benanain River flood. 
The findings from the above research were constructed by researchers based on researchers' big questions about how the disaster management of the Malaka Regency government in flood disaster management. Based on the research construction and the explanation that the researchers have done, the researchers can draw big conclusions related to this research, namely the disaster management of the Malaka Regency government in flood disaster management has been carried out as well as possible but still does not have an optimal role so that flood disaster is a problem. Main BPBD Malaka Regency still frequently occurs every year.

\section{Research methodology}

This research was conducted in Malaka Regency. The approach used in this research is the post-positivism paradigm. The research method used in the disaster management research of the Malaka Regency government in flood disaster management is a method that is relevant to the research objectives described in the previous chapter, namely by using a qualitative research method with the type of case study. The informants in this study were government elements, namely the Regional Secretary of the Malaka Regency, the Head of the BPBD of the Malaka Regency, the BPBD Employees of the Malaka Regency, the Camat, the Village Head and the elements of the Community consisting of the Flood Victims Community. This study's type of data came from primary data and secondary data, while the data collection techniques in this study used interviews, observation, and documentation. The analysis technique in this study uses data analysis developed by Miles and Huberman (2014: 10) as follows; (a) data reduction, (b) data display and (c) concluding. The researcher verified the conclusions during the study, the meanings that emerged from the data that were tested for validity, their suitability that was the key as their validity, so that their truth and usefulness would be clear. In this study, the triangulation technique that the researcher uses is that developed by (Denzim in Moleong, 2015: 331); there are four triangulations as an examination technique to achieve validity, namely:

1. Researchers' data triangulation used various data sources such as documents and archives of the Malak Regency Government that the researchers obtained when conducting interviews.

2. Observer triangulation is the presence of observers outside the researcher who also checks the data collection results, such as asking for guidance from the lecturer who guided the researcher in compiling this paper.

3. Theory triangulation, namely the researcher uses Management theory to ensure that the data collected meets the requirements. In this study, the theory and several concepts used will be seen in the discussion chapter to use and test the data collection.

4. Triangulation methods, namely using methods such as interviews and documentation methods. In this study, researchers used the interview method with documentation obtained from several informants involved in disaster management of the Malaka Regency government in flood disaster management.

\section{Results and discussions}

The Malaka Regency Government has responded to flooding in the Benanain River, including overcoming various problems in flood disaster management. This policy is based on various laws and regulations and disaster management programs. In general, national disaster management policies are stipulated in Law Number 24 of 2007 concerning Disaster Management, Government Regulation Number 21 of 2008 concerning Implementation of Disaster Management, Government Regulation Number 22 of 2008 concerning Disaster Aid Funding and Management, Government Regulation Number 23 of 2008 concerning Participation of International Institutions and Foreign NonGovernment Organizations in Disaster Management, as well as Presidential Regulation Number 08 of 2008 concerning the National Disaster Management Agency.

At the central level, the government has formed an institution that has the task and function of implementing disaster management, namely BNPB. BNPB is a non-ministerial institution that has the main task of managing disasters at the national level, while at the provincial and district/city levels it is implemented by BPBD. In Law Number 24 of 2007 Article 12 concerning Disaster Management explains that BNPB has the following duties: 
1. Provide guidance and direction for disaster management efforts that include disaster prevention, emergency response management, rehabilitation and reconstruction in a fair and equal manner.

2. Determining standardization and needs for disaster management based on statutory regulations.

3. Delivering information on disaster management activities to the community.

4. Reporting the implementation of disaster management to the President once a month in normal conditions and at any time in a state of disaster emergency.

5. Use and account for national and international donations/assistance.

6. To account for the use of budgets received from the State Budget (APBN).

7. Carry out other obligations in accordance with statutory regulations.

8. Prepare guidelines for the formation of Regional Disaster Management Agencies (BPBD). In this task, BNPB carries out the functions referred to in Law Number 24 of 2007 Article 13 concerning Disaster Management, namely: (1) Formulating and stipulating policies for disaster management and handling refugees by acting quickly and precisely as well as effectively and efficiently. (2) Coordinating the implementation of disaster management activities in a planned, integrated and comprehensive manner. Whereas in Article 18 paragraph (2), local governments form BPBD, which consists of (a) Provincial level agencies led by officials at the level of the governor, and (b) Agencies at the district/city level led by an official at the provincial level under the regent/mayor.

According to Law Number 24 of 2007 Article 21 concerning Disaster Management, the BPBD of Malaka Regency has the following duties: (a) Establishing guidelines and directions in accordance with local government and BNPB policies regarding disaster management efforts which include disaster prevention, emergency response, rehabilitation and reconstruction in a fair and equal manner, (b) Determining standardization and the need for disaster management based on statutory regulations, (c) Preparing, stipulating and informing disaster-prone maps, (d) Preparing and establishing fixed procedures for disaster management, (e) Implementing management of disaster management disaster on its territory. In carrying out its duties and functions in dealing with natural disasters in Malaka Regency, especially in handling the Benanain River floods, the Malaka Regency Government has stated in the Malaka Regency BPBD program in early prevention and handling of victims of natural disasters 2019-2020.

Table 2.

Malaka District BPBD Program in Early Prevention and Management of Natural Disaster Victims 2019-2020

\begin{tabular}{|l|l|l|}
\hline No & Activities & Achievements \\
\hline 1 & $\begin{array}{l}\text { Mitigation and Monitoring of Disaster } \\
\text { Prone Areas. }\end{array}$ & $\begin{array}{l}\text { Early indications are disaster- } \\
\text { prone areas that support } \\
\text { development priority 1 and } \\
\text { development focus 6. }\end{array}$ \\
\hline 2 & $\begin{array}{l}\text { Assessing Details of Land Movement } \\
\text { in Disaster Prone Areas. }\end{array}$ & $\begin{array}{l}\text { Informed about the land } \\
\text { movement area as a form of } \\
\text { disaster preparedness that } \\
\text { supports the 1st development } \\
\text { priority and the 6th development } \\
\text { focus. }\end{array}$ \\
\hline 3 & $\begin{array}{l}\text { Planning for Post- } \\
\text { Disaster } \\
\text { Rehabilitation and } \\
\text { Reconstruction. }\end{array}$ & $\begin{array}{l}\text { Planned handling of post-disaster rehabilitation } \\
\text { and reconstruction }\end{array}$ \\
\hline 4 & Assessment/Loss Due to Disaster. & There is an emergency response policy material. \\
\hline 5 & $\begin{array}{l}\text { Distribution and Logistics } \\
\text { Arrangement. }\end{array}$ & Delivery of aid to victims precisely and quickly. \\
\hline
\end{tabular}




\begin{tabular}{|c|c|c|}
\hline 6 & $\begin{array}{l}\text { Strengthening Emergency Response } \\
\text { Facilities. }\end{array}$ & Improved Disaster management infrastructure. \\
\hline 7 & $\begin{array}{l}\text { Procurement of Task } \\
\text { Force Equipment. }\end{array}$ & $\begin{array}{l}\text { Increased disaster management facilities and } \\
\text { infrastructure. }\end{array}$ \\
\hline 8 & $\begin{array}{l}\text { Post-Disaster Management } \\
\text { Rehabilitation and Reconstruction } \\
\text { Assessment. }\end{array}$ & $\begin{array}{l}\text { Preparation of post-disaster management policy } \\
\text { materials }\end{array}$ \\
\hline 9 & $\begin{array}{l}\text { Disaster Preparedness } \\
\text { Socialization }\end{array}$ & $\begin{array}{l}\text { Informed community preparedness in disaster } \\
\text { management }\end{array}$ \\
\hline 10 & $\begin{array}{l}\text { Preparation of Disaster Emergency } \\
\text { Response Logistics in the form of } \\
\text { Clothing and Household Appliances. }\end{array}$ & $\begin{array}{l}\text { Availability of bufferstock for emergency } \\
\text { response assistance in the form of in-kind }\end{array}$ \\
\hline 11 & $\begin{array}{l}\text { Preparation of Natural Material Disaster } \\
\text { Emergency Response Logistics. }\end{array}$ & $\begin{array}{l}\text { Availability of bufferstock for emergency response } \\
\text { assistance in the form of clothes and household } \\
\text { tools. }\end{array}$ \\
\hline 12 & $\begin{array}{l}\text { Implementation of the Operations } \\
\text { Control Center (Pusdalops) Kab. } \\
\text { Malaka }\end{array}$ & $\begin{array}{l}\text { Increased percentage of services for the } \\
\text { PUSDALOPS for Disaster Management. }\end{array}$ \\
\hline 13 & $\begin{array}{l}\text { Community Based Disaster } \\
\text { Management Training. }\end{array}$ & $\begin{array}{l}\text { Increasing the capacity of } \\
\text { community members in disaster } \\
\text { management. }\end{array}$ \\
\hline 14 & $\begin{array}{l}\text { Disaster Emergency } \\
\text { Management }\end{array}$ & $\begin{array}{l}\text { Preparation of emergency } \\
\text { administrative documents. }\end{array}$ \\
\hline 15 & $\begin{array}{l}\text { Post-Disaster Rehabilitation and } \\
\text { Reconstruction Management }\end{array}$ & $\begin{array}{l}\text { Handling disaster victims until shelter remains } \\
\text { available }\end{array}$ \\
\hline 16 & $\begin{array}{l}\text { Operational Improvement of Task } \\
\text { Force/Quick Reaction Team }\end{array}$ & Handling disaster victims. \\
\hline 17 & $\begin{array}{l}\text { Development of a Disaster Awareness } \\
\text { Culture }\end{array}$ & $\begin{array}{l}\text { Implementing an understanding of disaster } \\
\text { awareness and culture. }\end{array}$ \\
\hline 18 & $\begin{array}{l}\text { Technical Assistance for Emergency } \\
\text { Aid Rescue and Evacuation. }\end{array}$ & Handling disaster victims. \\
\hline 19 & $\begin{array}{l}\text { Emergency Management Simulation for } \\
\text { Community/Students. }\end{array}$ & Handling disaster victims. \\
\hline 20 & $\begin{array}{l}\text { Verification and Distribution of Aid } \\
\text { for Disaster Emergency Response } \\
\text { Needs. }\end{array}$ & Handling disaster victims \\
\hline 21 & SAR Training (Basic and Advanced). & Handling disaster victims \\
\hline 22 & $\begin{array}{l}\text { Disaster Preparedness Socialization in } \\
\text { Schools. }\end{array}$ & Handling disaster victims \\
\hline
\end{tabular}

Source: BPBD of Malaka Regency October 2020 


\subsection{Disaster risk management/pre-disaster}

\subsubsection{Prevention}

Efforts made to prevent disasters from occurring (if possible by eliminating the hazards). For example, Prohibiting local people from littering, prohibiting rock mining in steep areas, and inviting people to choose the environment by diligently planting trees to maintain natural sustainability.

The study results found that disaster risk management related to the prevention of floods in the Benanain River, the local government of Malaka Regency has made efforts to prevent floods by disseminating flood hazards and inviting the public to create a comfortable environment by planting trees in the environment. Barren and not allowed to litter, even though the people affected by the flood are victims of the flow of river water when it rains from the direction of TTS and TTU.

Prevention of flooding is certainly the government's initial action in flood disaster management, the government's efforts or active efforts to prevent flooding, but the government cannot avoid natural disasters when it's time. For this reason, the government as the person in charge of this natural disaster takes precautions by disseminating floods to the surrounding community and what they should do to prevent flooding from coming.

When going down to the research location, the author found that people do not litter, no one has mined stones in steep areas, and many people have routinely planted trees for nature preservation. For this reason, it can be said that prevention efforts are efforts made to prevent disasters (if possible by eliminating hazards). For example, Prohibiting local communities by littering, prohibiting stone mining in steep areas, and inviting people to choose the environment by diligently planting trees so that the government has done the preservation of nature and accepted by the surrounding community.

\subsubsection{Disaster mitigation}

Mitigation is a series of efforts to reduce disaster risk, either through physical development as well as awareness and increased capacity to face disaster threats. Mitigation activities can be carried out through:

1. Implementation of spatial planning

2. Development arrangements, infrastructure development, building layout.

3. Providing education, 26 counseling, and training both conventional and modern (Law Number 24 of 2007 Article 47 paragraph 2 concerning Disaster Management)

The study results found that the government had done this flood disaster mitigation effort as a pre-disaster action, such as coordinating with the central government so that in 2012 based on the Presidential Decree No. 12/2012 the Benanain River became five cross-country rivers. For this reason, a large Benanain dam was built for community agricultural land and also for flood prevention. In addition, the government has also built reservoirs along the river for mitigating this flood disaster. The government built embankments that are kilometers long, starting from the Hatimuk, Kleseleon, to Besikama areas. We do this to save people's assets, such as gardens containing agricultural products, houses, and other assets. However, if it is observed that the embankments are not optimal, which is the Benanain River's characteristic, which has very extreme discharge fluctuations so that the flow of the flowing water often breaks down the built embankments. This is evident on 23 May 2020 the Benanain River went berserk with the occurrence of flooding in 3 sub-districts, which were flooded. This is because within a week there is very high rainfall and it causes the river Benanain to overflow so that the embankments built by the government are not functioning. As a result of the flood disaster, the community suffered significant losses because their rice fields were flooded.

\subsubsection{Preparedness}

Preparedness is a series of activities carried out to anticipate disasters by organizing and taking appropriate and efficient steps. Some forms of preparedness activities that can be carried out include:

1. Preparing and testing disaster emergency management plans.

2. Organizing, installing and testing early warning systems.

3. Provision and preparation of supplies for the fulfillment of basic needs.

4. Organizing, outreaching, training and rehearsing emergency response mechanisms. 
5. Preparing evacuation sites.

6. Compiling accurate data, information, and updating of procedures for disaster emergency response

7. Provising and preparing materials, goods and equipment for the fulfillment of the restoration of infrastructure and facilities.

The research found that the preparedness of the Malaka Regency government is facing this flood disaster, although still full of all limitations, such as inadequate flood detection tools, namely prototypes and other flood detection tools. To prepare this evacuation location, we usually coordinate with churches and schools that are not affected as temporary evacuation sites. In this preparedness, of course, we, from all walks of life, elements of society, the government, and the private sector work together to handle it. However, the government will continue to optimize this deficiency so that people can get safety when a flood occurs, both their lives and their assets. We optimize this preparedness through disaster response officers who are always on standby during the flood disaster season by conducting basic training on disaster response, providing supporting infrastructure, materials, and materials needed when a flood occurs. However, the Malaka Regency government has not carried out basic training also for communities around the Benanain River even though according to the mandate of Law Number 24 of 2007 it explains that people living in disaster-prone areas need to receive basic disaster response training intended to protect themselves from the dangers of floods. This information the researchers got when the researchers were in the field and made direct observations with people who were victims of natural disasters, where the people said that they had not received basic disaster response training, they got socialization but only about socialization to prevent flooding such as maintaining a clean environment, not mining rocks in river areas, and planting trees in barren environments. Whereas basic training on how the community's efforts or preparedness actions during a flood disaster are not provided with basic training by the Malaka Regency Government, this can cause problems for the community victims of the Benanain river flood disaster, where if a large-scale flood occurs, the community will experience problems in protect themselves and their families due to basic training that the Malaka Regency government did not carry out for the victims of the Benanain River flood disaster.

In this pre-disaster stage, researchers examined three aspects and found that first, prevention efforts were made to prevent disasters from occurring (if possible by eliminating the hazards). For example, Prohibiting local communities by littering, Prohibiting rock mining in steep areas, and inviting people to choose the environment by diligently planting trees so that the government has done preservation of nature and accepted by the surrounding community; The second is related to flood mitigation by constructing the embankments built by the Malaka Regency government, which was originally built by the Malaka district government. However, if it is observed that the embankments are not optimal, which is the Benanain River's characteristic, which has very extreme discharge fluctuations so that the flow of the flowing water often breaks down the built embankments. This is evident on 23 May 2020 the Benanain River went berserk with the occurrence of flooding in 3 subdistricts, which were flooded. This is because within a week there is very high rainfall and it causes the river Benanain to overflow so that the embankments built by the government are not functioning.

As a result of the flood disaster, the community suffered huge losses because their rice fields were flooded; and the third is related to the preparedness of the Malaka Regency government, which is an activity to anticipate the Benanain river flood disaster through organizing and taking appropriate and efficient steps so that when a flood occurs the community can be optimized to run well. The Malaka Regency government's readiness continues to be carried out by training for disaster response officers and providing the necessary facilities, infrastructure, materials, and logistical materials in the event of a flood in the Benanain River. However, the Malaka Regency government has not carried out basic training also for communities around the Benanain River even though according to the mandate of Law Number 24 of 2007 it explains that people living in disaster-prone areas need to receive basic disaster response training intended to protect themselves from the dangers of floods. This information the researchers got when the researchers were in the field where the community said that they had not received basic disaster response training, the socialization they received was only about socialization on preventing floods such as maintaining a clean environment, not mining rocks in river areas, and planting trees in barren environments. 


\subsection{Emergency/disaster management}

\subsubsection{Emergency Response}

Emergency response is a series of activities carried out immediately at the time of a disaster to deal with the bad impacts which include activities to rescue and evacuate victims, property, fulfillment of basic needs, protection, management of refugees, rescue, and restoration of infrastructure and facilities. Some of the activities carried out at the emergency response stage include:

1. Accurate and precise assessment of location, damage and resources.

2. Determination of the status of a disaster emergency.

3. Rescue and evacuation of people affected by disasters.

4. Fulfillment of basic needs

5. Protection of vulnerable groups

6. Immediate recovery of vital infrastructure and facilities (Law Number 24 of 2007 Article 48 concerning Disaster Management)

The results show that the emergency response of the Malaka Regency government in handling the Benanain River floods is related to the responsiveness of the government when a disaster occurs, it is known to be very responsive, this can be seen that when a disaster occurs, we deploy all emergency response officers to stand by $1 \times 24$ hours at the location to save victims when providing emergency assistance, namely the difficulty of evacuating people from their affected houses. Many people choose to stay at home. Some choose to move to their families rather than evacuate by the government to be gathered at an evacuation site prepared by the government. The community states that in relation to their temporary residence, the community prefers to stay at home, due to reasons they do not have the heart to leave, or people choose to go to families who are willing to accommodate them, people feel uncomfortable if they have to live in one place with many people.

Emergency response, which is a series of activities carried out by the Malaka Regency government immediately at the time of a disaster to deal with the bad impacts which include activities to rescue and evacuate victims, property, fulfillment of basic needs, protection, management of refugees, rescue, and restoration of infrastructure and facilities carried out very responsively when the flood disaster occurred with all kinds of efforts they had done actively by the Government of Malaka Regency. Regarding the evacuation carried out by the government by providing an evacuation place, it is not heeded by the community because the community's thoughts are still inadequate, where there are still people who feel that they do not have the heart to leave their houses which are submerged in water and also feel awkward if they have to be collected in one place by the government they chose to move to their families who were not affected by the flood. Direct monitoring reinforced this carried out by researchers when a large-scale flood disaster occurred in three sub-districts to be precise on 23 May 2020. Many people affected by the Benanain river flood were difficult to evacuate by the Malaka Regency Government. They prefer to stay in their homes that are affected by flooding, this is due to the inadequate thinking and thinking of the community, they do not want to leave their homes when a flood occurs because they think that home is part of their life so they don't dare to leave their house when the flood disaster hits.

\subsubsection{Emergency Assistance (relief)}

Emergency assistance is an effort to fulfill basic needs in the form of: Food, clothing, temporary shelter, health, sanitation and clean water when a natural disaster occurs. During natural disasters, emergency assistance is often carried out by various elements, namely the government, private sector, other communities, and other elements as observers such as NGOs/NGOs that pay attention to these natural disasters. For emergency aid for floods, the Benanain River was more dominated by the local government as the responsible party when a flood occurred.

The results of research related to government emergency assistance when a flood occurred in the Benanain River, the Malaka Regency government certainly provided the community's emergency assistance, we did many activities during a disaster because this was related to human values. In addition to the emergency responders who have to stand by at the location, we have prepared logistics for the community to be distributed to the community to get their basic needs such as food, clothing, temporary shelter, health, sanitation and clean water. 
Regarding the emergency assistance that the researchers received from the BPBD of Malaka Regency, this type of assistance can be seen in table bellow.

Table 3

Types of Assistance for Victims of the Benanain River Flood disaster

\begin{tabular}{|l|l|}
\hline Types of Assistance & Information \\
\hline Temporary relocation assistance & Channeled \\
\hline Basic needs assistance & Channeled \\
\hline Emergency equipment assistance & Channeled \\
\hline Physical repair assistance & Channeled \\
\hline Counseling/spiritual guidance assistance & Channeled \\
\hline Relief team assistance & Channeled \\
\hline Health Assistance & Channeled \\
\hline
\end{tabular}

Source: BPBD of Malaka Regency October 2020

Table 4.6 explains that when the Benanain River flood disaster occurred, emergency assistance was properly distributed to the flood victims. The results of direct observations by researchers when they were in the flood location on May 23, 2020, where there was a large-scale flood that inundated 7,495 houses and when it happened the researchers took to the field to observe firsthand how emergency assistance was distributed to victims of the Benanain river flood disaster and found the emergency assistance with quickly descended and distributed to the community so that the emergency assistance provided by the Malaka Regency government was very helpful for the communities affected by the Benanain River flood.

At this stage of Emergency Management/During Disaster two aspects were examined by researchers and found that, first, emergency response is a series of activities carried out by the Malaka Regency government immediately at the time of a disaster to deal with the bad effects which include rescue and evacuation of victims, property, fulfillment of basic needs, protection, care for refugees, rescue, and restoration of infrastructure and facilities are carried out very responsively when a flood occurs with all kinds of efforts they do. Regarding the evacuation carried out by the government to a place that has been provided by the government which is not heeded by the community because of the inadequate thinking of the community, where some people still feel that they do not have the heart to leave their houses which are submerged in water and also feel awkward if they have to be collected in one place by government so they choose to move to their families who are not affected by the flood; and the second is emergency assistance, which is an effort to fulfill basic needs in the form of: food, clothing, temporary shelter, health, sanitation and clean water when a natural disaster occurs and is properly distributed and accepted by the community.

\subsection{Recovery/Post Disaster Management}

4.3.1. Recovery

Recovery is a series of activities to restore the community's condition and environment by refunctioning institutions, infrastructure, and facilities by carrying out rehabilitation efforts. Some of the activities related to recovery are:

1. Improvement of the disaster area environment

2. Repair of public infrastructure and facilities

3. Providing assistance for community housing repairs

4. Psychological social recovery

5. Health services

6. Reconciliation and conflict resolution 
7. Socio-economic and cultural recovery

8. Restoration of public service functions.

The results of the study found that the post-flood disaster of the Benanain River, the role of the government in it continues to run, and this is also the hard work that the government is doing where the government needs to restore all forms of damage that have occurred, especially physical and psychological damage to people who have experienced trauma, especially children and women. Recovery of infrastructure facilities such as roads, residents' houses, and agriculture as well, the government distributed to the community after the disaster with the procedures and regulations that we have set. Of course we try to get all the people to get the assistance that is their right. We also do other recovery such as community psychology, especially children, by deploying medical personnel, doctors, nurses, and psychologists so that the community can get recovery so that it can be said that recovery is a series of activities to restore the condition of the community and the environment affected by the disaster by re-functioning institutions. Infrastructure and facilities by carrying out rehabilitation efforts are carried out by the government carefully. However, in practice, the government has experienced constraints with a lack of funds up to the post-disaster stage and also for the repair of the embankments while being reviewed by the Malaka Regency government in coordination with the Province and the Central.

\subsubsection{Reconstruction}

Reconstruction is the formulation of policies and efforts as well as concrete, well-planned, consistent and sustainable steps to rebuild all infrastructure permanently, facilities and institutional systems, both at the government and community levels, with the main objective of growing and developing economic, social and cultural activities, upholding law and order, and the emergence of the role and participation of civil society in all aspects of social life in post-disaster areas. The scope of the reconstruction program consisted of a physical reconstruction program and a non-physical reconstruction program.

The reconstruction of facilities and infrastructure that were severely damaged due to the flood disaster is the government's priority program in post-disaster reconstruction efforts. The government is coordinating with the relevant OPDs on how to reconstruct the infrastructure that was swallowed up by the flood disaster of the Benanain River, such as the embankments, roads, bridges and other irrigation. Because it was linked to the program for reconstruction, it was not decided by just one OPD, so it can be said that reconstruction is an effort and concrete steps that are well planned, consistent and sustainable to permanently rebuild all infrastructure, facilities and institutional systems damaged by river floods. Benanain has been carried out in coordination with related OPDs to reconstruct the infrastructure damaged by the Flood of the Benanain River. Researchers also found this when descending into the field where some roads and embankments were severely damaged by the Benanain River flood disaster and reconstructed immediately by the Malaka Regency Government.

Management of the Post-disaster Malaka District BPBD explained two focuses were observed to believe that recovery is a series of activities to restore the condition of the community and environment affected by the disaster by re-functioning of institutions, infrastructure and facilities by carrying out rehabilitation efforts carried out by the government carefully, although in practice the government experiencing constraints with a lack of funds up to the post-disaster stage and also for the repair of the embankments while being reviewed by the Malaka Regency government in coordination with the Province and the Central and secondly, namely reconstruction which is an effort and concrete steps that are well planned, consistent and sustainable To rebuild permanently all infrastructure, facilities and institutional systems damaged by the floods of the Benanain River, this has been carried out in coordination with related OPDs so that they can work together in reconstructing facilities and Infrastructure was damaged due to the Benanain River Flood. Researchers also found this when descending into the field where some roads and embankments were severely damaged by the Benanain River flood disaster and reconstructed immediately by the Malaka Regency Government. 


\section{Conclusion}

Based on the results of the research and discussion discussed in the previous chapter, the conclusions drawn in the paper regarding the disaster management of the Malaka Regency Government in flood disaster management have carried out management as well as possible, although still not optimal. The basis of the analysis used is to use a disaster management model, which is seen from the following 3 things:

The Pre-Disaster Stage or disaster risk management is the management of prevention, mitigation, and preparedness for the Benanain River disaster management which the Malaka Regency government predicts to run well, but in practice at the mitigation stage there are problems with embankments that are often built, where the embankments are not suitable with the discharge of water that flows when the flood comes so that the embankment often breaks. And the suboptimal preparedness stage, namely at the community level, has not carried out basic disaster response training.

When a disaster occurs or emergency management is disaster management that is anticipated by the Malaka Regency government, which includes emergency response activities and emergency assistance to alleviate temporary suffering when the Benanain river floods run well where the Malaka Regency government is very responsive in handling when floods occur. However, during the emergency response, community participation involves evacuating people whose houses are affected by flooding, which is still difficult to do where there are people who do not want to be evacuated and have remained in their flooded houses.

The post-disaster or recovery management stage is disaster management that is anticipated by the Malaka Regency government including recovery and reconstruction activities for the victims of the Benanain flood disaster, where the government tries to coordinate with all layers of elements to restore what happened after the Benanain River flood disaster.

\section{Limitation and study forward}

This study's limitation is that the research was only conducted in one area, namely Malaka district. In fact, there are still many areas in East Nusa Tenggara that have experienced similar disasters but with different field conditions. Further researchers are encouraged to be able to carry out similar research in other areas so that there is a comparison between other areas experiencing similar disasters.

\section{References}

Badan Informasi Publik Departemen Komunikasi dan Informatika. (2007). Penanggulangan bencana alam dalam perspektif agama di Indonesia. Badan Informasi Publik Departemen Komunikasi dan Informatika: Jakarta.

BPBD Kabupaten Malaka. (2020). Alokasi anggaran untuk penanggulangan bencana di Kabupaten Malaka.

bpbd.bogorkab.go.id. (2019). Bencana dan manajemen bencana. Diakses pada 7 Januari 2021, dari https://bpbd.bogorkab.go.id/bencana-dan-manajemen-bencana/

Dwiyanto, Agus. (2010). Manajemen pelayanan publik. Yogyakarta:Gadja Mada

Fayol, Henry. (2010). Manajemen public relations. Jakarta: PT Elex Media.

Pemerintah Pusat. (2012). Keputusan Presiden (KEPPRES) tentang Penetapan Wilayah Sungai. The Government of Indonesia.

Kompas.com. (2020). Penyebab banjir di Indonesia. Diakses pada 7 Januari 2021, dari https://hot.liputan6.com/read/3924215/5-cara-menulis-daftar-pustaka-dari-internet-wajibtahu-agar-tidak-salah

Kustiyanto, Eko. (2004). Aplikasi Sistem Informasi Geografis untuk zonasi tingkat kerentanan banjir (Studi kasus kabupaten Kudus, Provinsi Jawa Tengah). Tugas Akhir Diploma. Fakultas Geografi UGM.

Miles, M.B, Huberman, A.M, \& Saldana, J. (2014). Qualitative data analysis, a methods sourcebook, Edition 3. USA: Sage Publications. Terjemahan Tjetjep Rohindi Rohidi, UI-Press.

Moleong, L. J. (2015). Metodologi penelitian kualitatif, Bandung : PT Remaja Rosdakarya Offset.

Nurjanah, dkk. (2011). Manajemen bencana. Bandung:Alfabeth.

Terry, R. George. (2003). Dasar-dasar manajemen. Jakarta: PT. Bumi Aksara

Wirawan, S. (2002). Psikologi lingkungan. Jakarta: PT Gramedia Widiasarana Indonesia. 
Pemerintah Republik Indonesia. (2007). Undang-Undang Nomor 24 Tahun 2007 tentang penanggulangan bencana. Lembaran Negara Republik Indonesia Tahun 2007 Nomor 66. Sekertariat Negara. Jakarta.

Pemerintan Republik Indonesia. (2008). Peraturan Pemerintah Nomor 21 Tahun 2008 tentang penyelenggaraan penanggulangan bencana. Lembaran Negara Republik Indonesia Tahun 2008 Nomor 42. Sekertariat Negara. Jakarta.

Pemerintah Daerah Kabupaten Malaka. (2015). Peraturan Daerah Kabupaten Malaka Nomor 5 Tahun 2015 tentang pembentukan organisasi dan tata kerja badan penanggulangan bencana daerah. Sekertariat Daerah Kabupaten Malaka. 